\title{
The Efficacy and Safety of Topical Microbicide Gels to Prevent Sexual Transmission of Human Immunodeficiency Virus (HIV) Infection: a Systematic Review and Meta-analysis
}

Jamie Gillies-Podgorecki ( $\square$ umgilli4@myumanitoba.ca )

University of Manitoba College of Medicine https://orcid.org/0000-0001-9134-9985

\section{Sarah van Gaalen}

University of Manitoba

Tiba Abdulwahid

University of Manitoba

Marissa Becker

University of Manitoba

Mê-Linh Lê

University of Manitoba

\section{Rasheda Rabbani}

University of Manitoba

Ryan Zarychanski

University of Manitoba

Ahmed M. Abou-Setta

University of Manitoba

\section{Research}

Keywords: HIV, Prevention, Topical, Microbicides, Gel, Prophylaxis

Posted Date: January 4th, 2021

DOI: https://doi.org/10.21203/rs.3.rs-137728/v1

License: (9) (1) This work is licensed under a Creative Commons Attribution 4.0 International License. Read Full License 


\section{Abstract}

Background: Topical microbicide gels are a potential method to reduce sexually transmitted human immunodeficiency virus (HIV) infection, especially in women. Several randomized controlled trials (RCTs) of topical microbicides to prevent HIV transmission have yielded promising results, however trial results have been inconsistent. The objective of this study was to determine the efficacy and safety of topical microbicide gels to prevent HIV transmission.

Methods: We conducted meta-analyses, stratified by microbicide gel type, using a random-effects model. We included 25 RCTs that met the inclusion criteria: 13 RCTs examined gel efficacy during heterosexual contact, and an additional 12 trials reported on gel acceptability, participants' adherence to intervention, and adverse reactions (allergic reaction and pain).

Results: With this limited data, topical microbicide gels were not found to be significantly better than placebo in preventing HIV infection (risk ratio (RR) $0.93,95 \% \mathrm{Cl} 0.82$ to $1.04 ; \mathrm{I}^{2} 14 \% ; 13$ trials; 31,764 participants). It should be noted that low adherence rates were frequently reported within trials. In one trial with high participant adherence $(>70 \%)$ to intervention, there was a significant protective effect of gels (RR $0.63,95 \% \mathrm{Cl} 0.43$ to $0.93 ; 889$ participants). While measures of acceptability and adherence to intervention were similar between groups, administration of topical microbicides were associated with an increased incidence of pain at the application site (RR $1.16,95 \% \mathrm{Cl} 1.00$ to $1.36, \mathrm{I}^{2} \mathrm{0} \%, 15$ trials, 19,554 participants).

Conclusions: In conclusion, efficacy of topical microbicide gels may relate to baseline risk and compliance with the intervention. In the general population it is not associated with protection from sexually transmitted HIV infection.

\section{Introduction}

Globally, human immunodeficiency virus (HIV) affects over 38 million people, with 2.1 million new infections diagnosed in 2015 (1). Women are disproportionately affected by the HIV epidemic in Africa; the continent that accounts for more than $70 \%$ of the global burden of HIV (2). Unprotected sexual contact is responsible for the majority of new cases worldwide, and a clear need exists for new technologies to prevent HIV transmission, particularly methods that are female controlled methods.

As there is currently no cure for HIV, nor vaccine to prevent infection, the control of the HIV epidemic is dependent upon other biomedical, behavioural and structural prevention interventions, and life-long treatment regimens for those that are infected; all of which have substantial individual, social and economic impacts (3). Currently, HIV prevention includes education and awareness of HIV risk factors, promotion of condom use, the use of pre-exposure prophylaxis, male circumcision, and structural interventions such as violence reduction (4). These practices, however, are largely partner-dependent, and barriers to use can limit their impact on incidence rates in women, especially in sub-Saharan Africa where young women bear the greatest HIV burden (4). Additional strategies to prevent the spread of HIV, particularly those that women can use and control, remain a pressing priority (5).

Topical microbicide gels are applied to the vagina or rectum pre-exposure with the intention of reducing sexually transmitted HIV. These gels may potentially prevent both male-to-female and female-to-male transmission. If proven effective and safe, topical microbicide gels would be an important addition to the prevention toolkit. In phase I clinical trials, topically applied microbicide gels were shown to be acceptable and well tolerated by both HIV-negative and -positive women (6-12). However, the efficacy and safety of topical gels to prevent sexual transmission of HIV remains uncertain.

The objective of this systematic review is to identify, critically appraise and meta-analyze data from randomized trials evaluating topical microbicide gels to prevent sexually transmitted HIV infection.

\section{Methods}

We followed a published, a priori protocol (13) and conducted this systematic review in accordance to the Methodological Expectations of Cochrane Intervention Reviews (14). Reporting is in line with the Preferred Reporting Items for Systematic Reviews and Meta-Analyses (PRISMA) guidelines (15). 


\section{Populations, Interventions, Comparators, Outcome Measures, and Study Designs}

We included only randomized, controlled trials of sexually active adult participants who were not found to be HIV positive. Our primary research question was "What is the safety and efficacy of topical microbicide gels to prevent sexually transmitted HIV infection?" The main outcome measure was laboratory confirmed HIV infection. Secondary outcomes included patient adherence to intervention, and patient acceptability of intervention. Safety outcomes included allergic reaction and pain at application site. Inclusion and exclusion criteria are presented in the appendices.

\section{Search strategy for identification of studies}

We searched MEDLINE (Ovid), EMBASE (Ovid), and CENTRAL (Cochrane Library - Wiley) from inception to March 2019 using individualized search strategies prepared for each database using the Cochrane Highly Sensitive Search Strategy as a model. The MEDLINE search, which was reviewed by a second information specialist using the Peer Review for Electronic Search Strategies (PRESS) template (16) is presented in the Appendix. To identify additional relevant citations, we performed a forward search in Scopus and Web of Science. To identify ongoing or planned trials we searched the World Health Organization's International Clinical Trials Registry Platform.

We searched abstracts and conference proceedings (2011-2019) for the following societies: British HIV Association, Conference on Retroviruses and Opportunistic Infections, The International Society for Sexually Transmitted Disease Research, International AIDS Society, Forum for Collaborative HIV Research, Canadian Association for HIV Research and UNAIDS. Reference lists of relevant narrative and systematic reviews and included trials were hand-searched for possible relevant citations. Reference Management was performed in EndNote ${ }^{\text {TM }}$ (ver. X7, Thompson Reuters, 2016, New York, NY, USA).

We used a two-step process for study selection. First, two reviewers (JG and SV) independently screened the titles and abstracts (when available) of search results to determine if a study met the general inclusion criteria. The full texts of relevant citations were then reviewed in duplicate to determine eligibility of inclusion. Data from trial reports were extracted in duplicate (JG, SV, TA) using a standardized form and entered into a Microsoft Excel ${ }^{\mathrm{TM}}$ database (Microsoft Corp., Redmond, WA).

The following data were extracted from each trial: author identification, year of publication, language of publication, source of study funding, study design, risk of bias criteria (see below), study population (including study inclusion and exclusion criteria), patient characteristics (e.g. age, sex, HIV status, sexually transmitted infection status), intervention and its comparator, and results reported for the outcomes of interest. As needed, authors were contacted for further information about their trials. For both study selection and data extraction, disagreements were resolved by discussion between the two reviewers or by third-party adjudication (AMAS), if required.

\section{Risk of Bias Assessment}

The internal validity of trials was assessed by using the Cochrane Collaboration Risk of Bias tool $(17,18)$. This tool consists of six domains (sequence generation, allocation concealment, blinding, incomplete outcome data, selective outcome reporting, and other sources of bias) and a categorization of the overall risk of bias. Information regarding risk of bias was used to guide sensitivity analyses and explore sources of heterogeneity.

\section{Measures of Intervention Effect}

The data from the included trials was analyzed using Review Manager (RevMan version 5.3.5, Copenhagen: The Nordic Cochrane Centre, The Cochrane Collaboration, 2014). Pooled dichotomous data is presented as a risk ratio (RR) with $95 \%$ confidence intervals (Cl). Statistical heterogeneity was explored and quantified using the l-squared statistic (19).

\section{Subgroup Analyses}

To determine summary effect estimates in several strata, including: type of microbicide used, participant adherence to intervention, and participant demographics (women at high risk of HIV infection, women at low/moderate risk of HIV infection).

\section{Publication Bias}


Publication bias was assessed using funnel plot techniques, as appropriate, given the known limitations of these methods (20).

\section{Results}

\section{Trial Characteristics \& Study Populations}

Of 1,947 records identified from electronic and hand searches, we included 25 unique RCTs (36,319 participants) that met our inclusion criteria (Fig. 1). Of these, 13 trials (31,764 participants) evaluated the efficacy to prevent sexually transmitted HIV infection of seven different microbicide gels (21-33). These trials included strictly female participants and evaluated HIV transmission during heterosexual contact. None of these trials assessed the efficacy of topical microbicide gels to prevent HIV transmission during anal sex. The Van Damme 2008 (27) and Halpern 2008 (25) Cellulose Sulphate (CS) trials were stopped early after the Data Safety Monitoring Board (DSMB) determined that the CS gel may increase the risk of HIV infection when compared with placebo. A single trial of 2\% PRO 2000 (34), a single trial of Tenofovir (32) and two SAVVY trials $(23,24)$ were stopped early due to low event rates.

We included twelve additional trials reporting on the secondary and safety outcomes of interest. Overall, nine trials $(28,29,35-41)$ evaluated gel acceptability (1,758 participants), 7 trials $(21,28,31,36,40,42,43)$ evaluated participants' adherence to intervention (2,417 participants), 20 trials (21, 23-28, 30-36, 38, 40, 41, 43-45) evaluated allergic reaction (31,605 participants) and 15 trials $(21,23,24,28,29,31,32,34-37,41,43,45,46)$ evaluated pain (19,555 participants).

The age of trial participants included in this review ranged from 16 to 72 years. Twenty-three of the trials $(21,23-34,36,39,41-$ 46) included female participants only. Five trials (21-25) identified their participants as being at high risk of HIV infection); one trial (37) enrolled heterosexual couples (although only reported on outcomes of interest from female participants); and one trial (40) enrolled both males and females with a previous history of receptive anal intercourse (RAl). The two trials $(35,40)$ that assessed male participants examined secondary outcomes only. All trials counselled and supplied free condoms to all the 26,319 participants (100 males and 36219 females). Participants were instructed to use these barrier methods for all acts of sexual intercourse regardless of gel use. One trial (40) instructed participants to abstain from RAl during the trial.

The type and dose of active ingredient, along with frequency of application varied across the included trials; however, a placebo gel was consistently used as the comparator. Eleven different microbicide gels were included, namely, cellulose sulphate (CS) $(25,27$, 36); SAVVY (23, 24); PRO 2000 (30, 34); Buffer- Gel (30); Carraguard (26, 29, 37, 46); Viva Gel (31); Nonoxynol-9 (21, 40, 42, 44, 45); Dapirivine (39); Dextrin Sulphate (35); Polymer Gel (43); and Tenofovir (28, 32, 33, 40,41). Of these, seven trials used two different anti-retroviral (ARV) gels, namely, Dapirivine, and Tenofovir and the other microbicides were non-ARV based.

\section{Risk of bias of included studies}

Overall, most trials $(16 / 25)(21,26,27,29,31,33,35-38,40-44,46)$ were adjudicated to be of unclear risk of bias, while the remaining trials $(23-25,28,30,32-34,45)$ were considered at low risk of bias. Most trials had adequate random sequence generation (20/25), allocation concealment (20/25) and blinding of outcome assessment (22/25), and low risk of attrition bias (24/25), however the majority were subject to unclear (16/25) risk of selective outcome reporting due to the unavailability of a protocol. Our judgments about the risk of bias in each included study are summarized in Fig. 2.

\section{Primary Outcome - HIV infection}

In the general female population, we found no evidence that topical microbicide gels modified the rate of new HIV infection (21, 23-30, 32-34, 42) (Risk Ratio (RR) 0.93, 95\% Cl 0.82 to 1.04; I 14\%; 13 trials; 31,764 participants; Fig. 3). However, variability was seen across the sub-populations. In women at average-/ low-risk of HIV infection, microbicide gels were associated with a significant reduction in the risk of new HIV infections (RR $0.88,95 \% \mathrm{Cl} 0.79$ to $0.99 ; 1^{2} 0 \%$; 8 trials; 24,655 participants); while in women identified as being at high risk of HIV infection, topical microbicides did not reduce HIV infection (RR $1.14,95 \% \mathrm{Cl} 0.85$ to $1.52 ; I^{2} 8 \% ; 5$ trials; 7,109 participants). Further, in a subgroup analysis that considered if participant adherence modified treatment effect, we found that in one trial (889 participants identified as at average-/low-risk of HIV infection) where $>70 \%$ of participants complied with their instructed gel regimen, new HIV infections were significantly reduced (RR $0.63,95 \% \mathrm{Cl} 0.43$ to 0.93 ; Appendices 
Figs. 1 and 2). The opposite was also evident wherein a single trial (892 participants identified as at high risk infection) reporting < $70 \%$ participant adherence, the microbicides were not associated with reduced rates of HIV infection (RR $1.29,95 \% \mathrm{Cl} 0.90$ to 1.86 ).

\section{Secondary Outcomes}

\section{Acceptability}

Acceptability data was presented for nine different trials (8 publications) $(28,29,35-38,40,41)$. Acceptability was presented as the proportion (\%) of participants that either liked the gel or would be likely to use it again. We found no statistically significant difference in acceptability between the intervention and control groups (RR 0.99, $95 \% \mathrm{Cl} 0.95$ to $1.04 ; I^{2} 0 \% ; 1,758$ participants;).

\section{Adherence}

Adherence was reported in seven trials $(21,28,31,36,40,42,43)$. Adherence was measured as the proportion of participants who followed their instructed intervention regimen. Reporting of participant adherence varied by trial; four trials $(21,40,42,43)$ used participant self-report, whereas three trials $(28,31,36)$ use both self-report in addition to accounting for the number of used and unused applicators returned by participants. There was no clear association between the type of microbicide and adherence to intervention (versus placebo gel) (RR $0.99,95 \% \mathrm{Cl} 0.94$ to $1.04 ; \mathrm{I}^{2} \mathrm{0} \% ; 2,417$ participants).

\section{Safety Outcomes}

Topical microbicide gels were not associated with allergic reactions, reported as either allergic reaction to product or adverse events such as redness, itchiness, or inflammation in gel application area $(21,23-28,30-36,39-41,43-45)(\mathrm{RR} 1.05,95 \% \mathrm{Cl} 0.96$ to $1.14, I^{2} 6 \%, 18$ trials, 29,545 participants). The administration of topical microbicides was associated with increased incidence of pain at application site (RR $1.16,95 \% \mathrm{Cl} 1.00$ to $1.36, \mathrm{I}$ \% , 15 trials, 19,554 participants). Of these fifteen trials $(21,23,24,29-$ $32,34-37,41,43,45,46)$ reporting pain, $3.5 \%$ of participants in the active gel groups reported pain in the application area, compared to $2.8 \%$ of participants in the placebo gel groups. However, neither group listed pain as a reason for discontinuation. Severity and/or type of pain were not reported in a consistent manner among trials.

\section{Discussion}

In this systematic review and meta-analysis, we found that topical microbicide gels did not provide a protective effect against the transmission of heterosexually acquired HIV infection. Our review provides a timely update to the 2012 Cochrane review that examined the efficacy of topical microbicide gels to prevent HIV and other sexually transmitted infections. This previous review included solely female participants, did not include the microbicide nonoxynol-9 and, most importantly, new evidence has become available since this review was published. Our review is also the first to address the efficacy of topical microbicide gels to prevent sexual transmission of HIV among women, in trials published up until March 2019 (capturing five new trials, involving 5632 participants examining the primary outcome), in addition to evaluating gel acceptability, adherence, pain and allergic reaction among men and women.

Overall, no significant difference was found between the active and placebo groups in the incidence of HIV transmission, acceptability, adherence to intervention, or allergic reaction. While the application frequencies, mode of application, mode of microbicidal action, and placebos used in the included trials differed, the end result was expected to be the same (e.g. prophylaxis), and we do not believe there is a strong enough rationale to consider the treatments different. Furthermore, the results from the individual studies were not statically different from one other. After systematic evaluation of these new and extended trial results, we conclude that there is still insufficient evidence to recommend topical microbicides for the prevention of HIV transmission to the public. It is important to note that lack of efficacy may be due to low incidence of HIV within the tested populations; thereby needing a much larger sample size to detect a statistically significant difference between the groups.

At present, limited evidence suggests that average-/ low-risk females may benefit from a reduction in heterosexually acquired HIV with gel use. However, this subgroup consisted of five different active gels (Tenofovir, PRO 2000, Buffer Gel, Cellulose Sulphate, Carraguard) and none of these interventions showed a statistically significant reduction in HIV acquisition within their own subgroup of microbicide. It is important to note that this observational data was gathered using post-hoc risk analysis and should 
be used for hypothesis generation rather than confirmation. Our findings identify several unanswered questions and highlight opportunities for future research; for instance, the need to further consider the impact of participant adherence to intervention on microbicide efficacy. High participant adherence to intervention was associated with a statistically significant protective effect, however this was only demonstrated in one trial. Further research should continue the development and testing of new microbicides, as well as ways to support and measure adherence.

Above 70\% participant adherence rates in the Karim 2010 trial (28) demonstrated an increased protective effect which emphasizes the need for purposeful research into maintaining participant adherence throughout trials. The successful launch of an effective gel will depend on having in place appropriate mechanisms for distribution to the women who need it, along with a strategy for ensuring is being used appropriately and effectively. It is critically important to note that low rates of adherence to study interventions by participants have been commonly stated as limitations in many of the included studies, despite overall acceptability of gels being high. While adherence may explain the possible lack of evidence to support the use of microbicides, it is not a key component of 'intention-to-treat'. Poor adherence rates may greatly affect the overall efficacy of potential topical microbicides in a real-world application. There are many examples of this including the use of IUD and injectable birth control rather than oral contraceptive pills for national programs even though the latter is more efficient. Compliance of daily intake of the intervention decreases its overall effectiveness.

Lastly, there was a statistically significant increase in reported pain at the application site with the active gels; however reported pain varied greatly between trials. An average of $3.5 \%$ of participants in the active gel groups reported pain at application site, which is still relatively low. Further research is needed to assess pain associated with use of specific types of active gels, and with increased frequency of gel usage. The strengths of this review include the completeness of the search strategy, including searching multiple citation databases, trial registries and conference abstracts. We focused on patient-centered outcomes and evaluated efficacy in the context of relevant safety outcomes and adverse events. Finally, we used an a priori published protocol and followed established methodological guidelines in the conduct and reporting of this review. This review is limited by the relatively high variability of risk of HIV acquisition between trial participants, which may restrict the broad generalizability of these findings. Additionally, the demographics of participants may not be representative of all populations at risk of acquiring HIV. Lastly, subgroup analyses were susceptible to type II errors due to relatively small sample sizes.

\section{Authors' Conclusion}

At present, the use of topical microbicide gels is not associated with protection from sexually transmitted HIV infection in the general population. As such, there is not enough evidence to recommend topical microbicide gels for regular use. Efficacy however might relate to baseline risk and compliance with the intervention. Further investigation into microbicide gels for HIV prevention should include targeted measures to increase adherence to intervention within specific subgroups (e.g. high-risk females, average- $/$ low-risk females, men who have sex with men). Lastly, if microbicides are found to be effective, they would need to be incorporated into a broad comprehensive prevention program.

\section{Declarations}

\section{Ethics approval:}

Not applicable.

\section{Consent to participate:}

Not applicable.

\section{Consent for publication:}

All authors approved the manuscript and this submission.

\section{Funding:}


We did not obtain any specific funding for this systematic review. Ryan Zarychanski receives salary support from the Canadian Institutes for Health Research (CIHR), while Marissa Becker is supported by a CIHR New Investigator Award. This entity had no role in the design and conduct of the study; collection, management, analysis, or interpretation of the data; and preparation, review, or approval of the manuscript.

\section{Conflicts of interest/Competing interests:}

None of the authors have a commercial or other association that might pose a conflict of interest. There are no conflict of interests.

\section{Acknowledgements:}

We would like to graciously thank the following authors and institutions for providing us with additional information on their trials: Barbara Friedland; Barbra Richardson; Hal Martin; CAPRISA; Charles Lacey; Cheryl Baxter; Craig Hendrix; Helen Rees; Sinead Delany-Moretlwe; lan McGowan; Cindy Jacobson; Irving Hoffman, Lynda Emele; Cliff Kelly; Jeanne Marrazzo; Lut Van Damme; Peter Kilmarx; Rabeea Omar; Vera Halpern.

\section{References}

1. World Health Organization UNAIDS. UNAIDS Fact Sheet 2016. Geneva, Switzerland: Joint United Nations Programme on HIV/AIDS and World Health Organization; 2016.

2. World Health Organization UNAIDS. AIDS Epidemic Update. Geneva, Switzerland: Joint United Nations Programme on HIV/AIDS and World Health Organization; 2009.

3. The United Nations. The Impact of AIDS. New York, The United States of America: Department of Economic and Social Affairs; 2004.

4. World Health Organization UNAIDS. Report on the Global AIDS Epidemic. Geneva, Switzerland: Joint United Nations Programme on HIV/AIDS and World Health Organization; 2006.

5. Karim SSA, Churchyard GJ, Karim QA, Lawn SD. HIV infection and tuberculosis in South Africa: an urgent need to escalate the public health response. the Lancet. 2009;374(9693):921-33.

6. Van Damme L, Chandeying V, Ramjee G, Rees H, Sirivongrangson P, Laga M, et al. Safety of multiple daily applications of COL1492, a nonoxynol-9 vaginal gel, among female sex workers. COL-1492 Phase II Study Group. AIDS (London, England). 2000;14(1):85-8.

7. Mayer KH, Peipert J, Fleming T, Fullem A, Moench T, Cu-Uvin S, et al. Safety and tolerability of BufferGel, a novel vaginal microbicide, in women in the United States. Clinical infectious diseases : an official publication of the Infectious Diseases Society of America. 2001;32:476-82.

8. Mayer KH, Karim SA, Kelly C, Maslankowski L, Rees H, Profy AT, et al. Safety and tolerability of vaginal PRO 2000 gel in sexually active HIV-uninfected and abstinent HIV-infected women. AIDS (London, England) [Internet]. 2003; 17(3):[321-9 pp.]. Available from: http://onlinelibrary.wiley.com/o/cochrane/clcentral/articles/981/CN-00412981/frame.html.

9. Bentley ME, Fullem AM, Tolley EE, Kelly CW, Jogelkar N, Srirak N, et al. Acceptability of a microbicide among women and their partners in a 4-country phase I trial. American journal of public health. 2004;94(7):1159-64.

10. Mayer KH, Maslankowski LA, Gai F, El-Sadr WM, Justman J, Kwiecien A, et al. Safety and tolerability of tenofovir vaginal gel in abstinent and sexually active HIV-infected and uninfected women. AIDS. 2006;20(4):543-51.

11. Smita J, Soma D, Bell B, Profy A, Kuruc JA, Fang G, et al. Phase I safety study of 0.5\% PRO 2000 vaginal Gel among HIV uninfected women in Pune, India. AIDS research and therapy [Internet]. 2006; 3(1):[4 p.].

12. Parikh U, Dobard C, Sharma S, al. e. Complete protection from repeated vaginal simian-human immunodeficiency virus exposures in macaques by a topical gel containing tenofovir alone or with emtricitabine. Journal of virology. 2009;3:10358-65.

13. Gillies-Podgorecki J. PROTOCOL: The efficacy of antiretroviral topical gels to prevent human immunodeficiency virus (HIV) infection: a systematic review and meta-analysis. [Protocol]. In press 2016. 
14. Churchill R, Higgins J, Chandler J, Tovey D, Lasserson T. Methodological Expectations of Cochrane Intervention Reviews. The Cochrane Collaboration; 2013.

15. Moher D, Liberati A, Tetzlaff J, Altman D, Group TP. Preferred Reporting Items for Systematic Reviews and Meta-Analyses: The PRISMA Statement. Annals of internal medicine. 2009;151(4):264-9.

16. McGowan J, Sampson M, Salzwedel D, Cogo E, Foerster V, Lefebvre C. PRESS peer review of electronic search strategies: 2015 guideline statement. Journal of Clinical Epidemiology. 2016;75(40).

17. Higgins J, Green S. Cochrane Handbook for Systematic Reviews of Interventions Version 5.1.0. 2011. The Cochrane Collaboration,. Available from: www.cochrane-handbook.org.

18. Higgins JP, Altman DG, Gøtzsche PC, Jüni P, Moher D, Oxman AD, et al. The Cochrane Collaboration's tool for assessing risk of bias in randomised trials. Bmj. 2011;343:d5928.

19. Higgins JP, Thompson SG. Quantifying heterogeneity in a meta-analysis. Statistics in medicine. 2002;21(11):1539-58.

20. loannidis J, Thompson S. The appropriateness of asymmetry tests for publication bias in meta-analyses: a large survey. Canadian Medical Association Journal. 2007;176(8):1091-6.

21. Richardson BA, Lavreys L, Martin Jr HL, Stevens CE, Ngugi E, Mandaliya K, et al. Evaluation of a low-dose nonoxynol-9 gel for the prevention of sexually transmitted diseases: A ramdomized clinical trial. Sexually Transmitted Diseases. 2001;28(7):394400.

22. Van Damme L, Jespers V, Van Dyck E, Chapman A. Penile application of dextrin sulphate gel (Emmelle). Contraception. 2002;66(2):133-6.

23. Peterson L, Nanda K, Opoku BK, Ampofo WK, Owusu-Amoaka M, Boakye AY, et al. SAVVY (C31G) gel for prevention of HIV infection in women: A phase 3, double-blind, randomized, placebo-controlled trial in Ghana. PLoS ONE. 2007;2(12):no pagination.

24. Feldblum PJ, Adeiga A, Bakare R, Wevill S, Lendvay A, Obadaki F, et al. SAVVY vaginal gel (C31G) for prevention of HIV infection: A randomized controlled trial in Nigeria. PLoS ONE. 2008;3(1):no pagination.

25. Halpern V, Ogunsola F, Obunge $\mathrm{O}$, Wang $\mathrm{C}-\mathrm{H}$, Onyejepu N, Oduyebo $\mathrm{O}$, et al. Effectiveness of cellulose sulfate vaginal gel for the prevention of HIV infection: results of a Phase III trial in Nigeria. PloS one. 2008;3(11):e3784.

26. Skoler-Karpoff S, Ramjee G, Ahmed K, Altini L, Plagianos MG, Friedland B, et al. Efficacy of Carraguard for prevention of HIV infection in women in South Africa: a randomised, double-blind, placebo-controlled trial. Lancet (London, England). 2008;372(9654):1977-87.

27. Van Damme L, Govinden R, Mirembe FM, Guedou F, Solomon S, Becker ML, et al. Lack of effectiveness of cellulose sulfate gel for the prevention of vaginal HIV transmission. The New England journal of medicine. 2008;359(5):463-72.

28. Abdool Karim Q, Abdool Karim SS, Frohlich JA, Grobler AC, Baxter C, Mansoor LE, et al. Effectiveness and safety of tenofovir gel, an antiretroviral microbicide, for the prevention of HIV infection in women. Science. 2010;329(5996):1168-74.

29. Carraguard Phase IISAST. Expanded safety and acceptability of the candidate vaginal microbicide Carraguard in South Africa. Contraception. 2010;82(6):563-71.

30. Abdool Karim SS, Richardson BA, Ramjee G, Hoffman IF, Chirenje ZM, Taha T, et al. Safety and effectiveness of BufferGel and 0.5\% PRO2000 gel for the prevention of HIV infection in women. AIDS (London, England). 2011;25(7):957-66.

31. McGowan I, Gomez K, Bruder K, Febo I, Chen BA, Richardson BA, et al. Phase 1 randomized trial of the vaginal safety and acceptability of SPL7013 gel (VivaGel) in sexually active young women (MTN-004). AIDS (London, England). 2011;25(8):1057-64.

32. Marrazzo JM, Ramjee G, Richardson BA, Gomez K, Mgodi N, Nair G, et al. Tenofovir-based preexposure prophylaxis for HIV infection among African women. New England Journal of Medicine. 2015;372(6):509-18.

33. Delany-Moretlwe S, Lombard C, Baron D, Bekker L-G, Nkala B, Ahmed K, et al. Tenofovir 1\% vaginal gel for prevention of HIV-1 infection in women in South Africa (FACTS-001): A phase 3, randomised, double-blind, placebo-controlled trial. The Lancet Infectious Diseases. 2018;18(11):1241-50.

34. McCormack S, Ramjee G, Kamali A, Rees H, Crook AM, Gafos M, et al. PRO2000 vaginal gel for prevention of HIV-1 infection (Microbicides Development Programme 301): a phase 3, randomised, double-blind, parallel-group trial. The Lancet. 
2010;376(9749):1329-37.

35. Low-Beer N, Gabe R, McCormack S, Kitchen VS, Lacey CJ, Nunn AJ. Dextrin sulfate as a vaginal microbicide: randomized, double-blind, placebo-controlled trial including healthy female volunteers and their male partners. JAIDS-HAGERSTOWN MD-. 2002;31(4):391-8.

36. Doh AS, Ngoh N, Roddy R, Lai JJ, Linton K, Mauck C. Safety and acceptability of $6 \%$ cellulose sulfate vaginal gel applied four times per day for 14 days. Contraception. 2007;76:245-9.

37. Kilmarx PH, Blanchard K, Chaikummao S, Friedland BA, Srivirojana N, Connolly C, et al. A randomized, placebo-controlled trial to assess the safety and acceptability of use of carraguard vaginal gel by heterosexual couples in Thailand. Sexually transmitted diseases. 2008;35(3):226-32.

38. Nel AM, Coplan P, Wijgert JH, Kapiga SH, Mollendorf C, Geubbels E, et al. Safety, tolerability, and systemic absorption of dapivirine vaginal microbicide gel in healthy, HIV-negative women. AIDS. 2009;23(12):1531-8.

39. Nel A, Smythe S, Young K, Malcolm K, McCoy C, Rosenberg Z, et al. Safety and pharmacokinetics of dapivirine delivery from matrix and reservoir intravaginal rings to HIV-negative women. JAIDS Journal of Acquired Immune Deficiency Syndromes. 2009;51(4):416-23.

40. McGowan I, Hoesley C, Cranston RD, Andrew P, Janocko L, Dai JY, et al. A phase 1 randomized, double blind, placebo controlled rectal safety and acceptability study of tenofovir 1\% gel (MTN-007). PloS one. 2013;8(4):e60147.

41. Bunge KE, Dezzutti CS, Hendrix CW, Marzinke MA, Spiegel HM, Moncla BJ, et al. FAME-04: A Phase 1 trial to assess the safety, acceptability, pharmacokinetics and pharmacodynamics of film and gel formulations of tenofovir. Journal of the International AIDS Society. 2018;21(8):e25156.

42. Van Damme L, Ramjee G, Alary M, Vuylsteke B, Chandeying V, Rees H, et al. Effectiveness of COL-1492, a nonoxynol-9 vaginal gel, on HIV-1 transmission in female sex workers: a randomised controlled trial. Lancet (London, England). 2002;360(9338):971-7.

43. Mbopi-Keou F-X, Trottier S, Omar RF, Nkele NN, Fokoua S, Mbu ER, et al. A randomized, double-blind, placebo-controlled Phase II extended safety study of two Invisible Condom ${ }^{\circledR}$ formulations in Cameroonian women. Contraception. 2010;81(1):79-85.

44. Van Damme L, Niruthisard S, Atisook R, Boer K, Dally L, Laga M, et al. Safety evaluation of nonoxynol-9 gel in women at low risk of HIV infection. AIDS. 1998;12(4):433-7.

45. Hoffman I, Taha T, Padian N, Kelly C, Welch J, Martinson F, et al. Nonoxynol-9 100 mg gel: multi-site safety study from subSaharan Africa. AIDS (London, England). 2004;18(16):2191.

46. Kilmarx PH, Wijgert JH, Chaikummao S, Jones HE, Limpakarnjanarat K, Friedland BA, et al. Safety and acceptability of the candidate microbicide Carraguard in Thai Women: findings from a Phase II Clinical Trial. Journal of acquired immune deficiency syndromes (1999) [Internet]. 2006; 43(3):[327-34 pp.]. Available from:

http://onlinelibrary.wiley.com/o/cochrane/clcentral/articles/260/CN-00572260/frame.html.

\section{Table}


Table 1

Characteristics of Included Studies

\begin{tabular}{|c|c|c|c|c|c|c|c|c|}
\hline Study ID & Intervention & Control & $\begin{array}{l}\text { Demo- } \\
\text { graphic }\end{array}$ & $\begin{array}{l}\text { Age } \\
\text { (mean) }\end{array}$ & $\begin{array}{l}\text { Frequency } \\
\text { of } \\
\text { Application }\end{array}$ & $\begin{array}{l}\text { Sample } \\
\text { Size }\end{array}$ & $\begin{array}{l}\text { Risk of } \\
\text { Bias }\end{array}$ & $\begin{array}{l}\text { Study } \\
\text { Location }\end{array}$ \\
\hline Bunge 2018 & Tenofovir & $\begin{array}{l}\text { HEC* Placebo } \\
\text { Gel }\end{array}$ & Females & 28 & $1 x /$ day & 78 & Unclear & USA \\
\hline $\begin{array}{l}\text { Carraguard } \\
\text { Team }\end{array}$ & $\begin{array}{l}\text { Carraguard } \\
\text { Gel }\end{array}$ & $\begin{array}{l}\text { Methylcellulose } \\
\text { Placebo Gel }\end{array}$ & Females & 27.8 & $3 x /$ week & 400 & Unclear & South Africa \\
\hline $\begin{array}{l}\text { Delany- } \\
\text { Moretlwe } \\
2018\end{array}$ & $\begin{array}{l}\text { Tenofovir } \\
\text { Gel }\end{array}$ & Placebo Gel & Females & 23 & $\begin{array}{l}1 \mathrm{x} \text { before } \\
\text { and after } \\
\text { every } \\
\text { vaginal } \\
\text { intercourse }\end{array}$ & 2059 & Unclear & South Africa \\
\hline Doh 2007 & $\begin{array}{l}\text { Cellulose } \\
\text { Sulphate } \\
\text { Gel }\end{array}$ & KY Jelly & Females & $\begin{array}{l}\text { Mid- } \\
20 \mathrm{~s}\end{array}$ & 4x/ day & 54 & Unclear & Cameroon \\
\hline $\begin{array}{l}\text { Feldblum } \\
2008\end{array}$ & SAVVY Gel & $\begin{array}{l}\text { HEC Placebo } \\
\text { Gel }\end{array}$ & $\begin{array}{l}\text { High Risk } \\
\text { Females }\end{array}$ & $\begin{array}{l}23.5 \\
(3.7)\end{array}$ & $\begin{array}{l}1 \mathrm{x} \text { before } \\
\text { each } \\
\text { vaginal } \\
\text { intercourse }\end{array}$ & 2153 & Low & Nigeria \\
\hline $\begin{array}{l}\text { Halpern } \\
2008\end{array}$ & $\begin{array}{l}\text { Cellulose } \\
\text { Sulphate } \\
\text { Gel }\end{array}$ & $\begin{array}{l}\text { HEC Placebo } \\
\text { Gel }\end{array}$ & $\begin{array}{l}\text { High Risk } \\
\text { Females }\end{array}$ & $\begin{array}{l}23.4 \\
(3.7)\end{array}$ & $\begin{array}{l}1 \mathrm{hr} \text {. before } \\
\text { every } \\
\text { vaginal } \\
\text { intercourse } \\
\text { (within } 24 \\
\text { hours) }\end{array}$ & 1644 & Low & Nigeria \\
\hline $\begin{array}{l}\text { Hoffman } \\
2004\end{array}$ & $\begin{array}{l}\text { Nonoxynol- } \\
9 \text { Gel }\end{array}$ & Placebo Gel & Females & 29 & $2 x /$ day & 180 & Unclear & $\begin{array}{l}\text { Malawi, } \\
\text { Zimbabwe }\end{array}$ \\
\hline Karim 2010 & $\begin{array}{l}\text { Tenofovir } \\
\text { Gel }\end{array}$ & $\begin{array}{l}\text { HEC Placebo } \\
\text { Gel }\end{array}$ & Females & 24.2 & $\begin{array}{l}1 \mathrm{x} \text { before } \\
\text { and after } \\
\text { every } \\
\text { vaginal } \\
\text { intercourse } \\
\text { (within } 24 \\
\text { hours) }\end{array}$ & 889 & Low & South Africa \\
\hline Karim 2011 & $\begin{array}{l}\text { PRO } \\
2000 / \text { Buffer } \\
\text { Gel }\end{array}$ & $\begin{array}{l}\text { HEC Placebo } \\
\text { Gel }\end{array}$ & Females & 26.2 & $\begin{array}{l}1 \mathrm{x} / \text { vaginal } \\
\text { intercourse }\end{array}$ & 2315 & Low & $\begin{array}{l}\text { Malawi, } \\
\text { South } \\
\text { Africa, } \\
\text { Zambia, } \\
\text { Zimbabwe, } \\
\text { USA }\end{array}$ \\
\hline $\begin{array}{l}\text { Kilmarx } \\
2006\end{array}$ & $\begin{array}{l}\text { Carraguard } \\
\text { Gel }\end{array}$ & $\begin{array}{l}\text { Methylcellulose } \\
\text { Gel }\end{array}$ & Females & 31.2 & $3 x /$ week & 165 & Unclear & Thailand \\
\hline $\begin{array}{l}\text { Kilmarx } \\
2008\end{array}$ & $\begin{array}{l}\text { Carraguard } \\
\text { Gel }\end{array}$ & $\begin{array}{l}\text { Methylcellulose } \\
\text { Gel }\end{array}$ & $\begin{array}{l}\text { Heterosexual } \\
\text { Couples }\end{array}$ & 33.71 & $\begin{array}{l}1 \mathrm{x} \text { before } \\
\text { each } \\
\text { vaginal } \\
\text { intercourse } \\
\text { (females } \\
\text { only) }\end{array}$ & $\begin{array}{l}55 \\
\text { couples }\end{array}$ & Unclear & Thailand \\
\hline $\begin{array}{l}\text { Low-Beer } \\
2002\end{array}$ & $\begin{array}{l}\text { Dextrin } \\
\text { Sulphate } \\
\text { Gel }\end{array}$ & Placebo Gel & Females & 29 & $\begin{array}{l}1 \mathrm{x} / \text { day } \\
\text { and } 1 \mathrm{x} \\
\text { before } \\
\text { vaginal } \\
\text { intercourse }\end{array}$ & 77 & Unclear & $\begin{array}{l}\text { United } \\
\text { Kingdom }\end{array}$ \\
\hline
\end{tabular}

*HEC = hydroxyethylcellulose gel; *RAI = receptive anal intercourse 


\begin{tabular}{|c|c|c|c|c|c|c|c|c|}
\hline Study ID & Intervention & Control & $\begin{array}{l}\text { Demo- } \\
\text { graphic }\end{array}$ & $\begin{array}{l}\text { Age } \\
\text { (mean) }\end{array}$ & $\begin{array}{l}\text { Frequency } \\
\text { of } \\
\text { Application }\end{array}$ & $\begin{array}{l}\text { Sample } \\
\text { Size }\end{array}$ & $\begin{array}{l}\text { Risk of } \\
\text { Bias }\end{array}$ & $\begin{array}{l}\text { Study } \\
\text { Location }\end{array}$ \\
\hline $\begin{array}{l}\text { Marrazzo } \\
2015\end{array}$ & $\begin{array}{l}\text { Tenofovir } \\
\text { Gel }\end{array}$ & HEC Placebo & Females & $\begin{array}{l}25.3 \\
(5.2)\end{array}$ & $1 \mathrm{x} /$ day & 2010 & Low & $\begin{array}{l}\text { South } \\
\text { Africa, } \\
\text { Uganda, } \\
\text { Zimbabwe }\end{array}$ \\
\hline $\begin{array}{l}\text { Mbopi-Keou } \\
2010\end{array}$ & $\begin{array}{l}\text { Polymer Gel } \\
\text { and } \\
\text { Polymer Gel } \\
\text { with } \\
\text { Sodium } \\
\text { Laurel } \\
\text { Sulphate }\end{array}$ & $\begin{array}{l}\text { HEC Placebo } \\
\text { Gel }\end{array}$ & Females & 30 & $2 x /$ day & 194 & Unclear & Cameroon \\
\hline $\begin{array}{l}\text { McCormack } \\
2010\end{array}$ & PRO 2000 & $\begin{array}{l}\text { HEC Placebo } \\
\text { Gel }\end{array}$ & Females & $\mathrm{N} / \mathrm{A}$ & $\begin{array}{l}1 \mathrm{hr} \text { before } \\
\text { each } \\
\text { vaginal } \\
\text { intercourse }\end{array}$ & 9385 & Low & $\begin{array}{l}\text { South } \\
\text { Africa, } \\
\text { Tanzania, } \\
\text { Uganda }\end{array}$ \\
\hline $\begin{array}{l}\text { McGowan } \\
2011\end{array}$ & Viva Gel & $\begin{array}{l}\text { Viva Gel } \\
\text { Placebo }\end{array}$ & Females & $\begin{array}{l}20.8 \\
(1.5)\end{array}$ & $2 x /$ day & 43 & Unclear & $\begin{array}{l}\text { United } \\
\text { States of } \\
\text { America, } \\
\text { Puerto Rico }\end{array}$ \\
\hline $\begin{array}{l}\text { McGowan } \\
2012\end{array}$ & $\begin{array}{l}\text { Tenofovir \& } \\
\text { Nonoxynol } \\
-9 \text { Gel }\end{array}$ & $\begin{array}{l}\text { HEC Placebo } \\
\text { Gel }\end{array}$ & $\begin{array}{l}\text { Males \& } \\
\text { Females } \\
\text { with a } \\
\text { history of } \\
\text { RAl* }\end{array}$ & 35.7 & $1 \mathrm{x} /$ day & 65 & Unclear & $\begin{array}{l}\text { United } \\
\text { States of } \\
\text { America }\end{array}$ \\
\hline $\begin{array}{l}\text { Nel } 2009 \\
\text { (IPM003) }\end{array}$ & $\begin{array}{l}\text { Dapivirine } \\
\text { Gel }\end{array}$ & $\begin{array}{l}\text { Dapivirine } \\
\text { Placebo }\end{array}$ & Females & 30 & $2 x /$ day & 112 & Unclear & $\begin{array}{l}\text { Rwanda, } \\
\text { South } \\
\text { Africa, } \\
\text { Tanzania }\end{array}$ \\
\hline $\begin{array}{l}\text { Nel } 2009 \\
\text { (IPM005B) }\end{array}$ & $\begin{array}{l}\text { Dapivirine } \\
\text { Gel }\end{array}$ & $\begin{array}{l}\text { HEC Placebo } \\
\text { Gel }\end{array}$ & Females & 30 & $2 x /$ day & 36 & Unclear & Belgium \\
\hline $\begin{array}{l}\text { Peterson } \\
2007\end{array}$ & SAVVY Gel & $\begin{array}{l}\text { HEC* Placebo } \\
\text { Gel }\end{array}$ & $\begin{array}{l}\text { High Risk } \\
\text { Females }\end{array}$ & $\begin{array}{l}22.7 \\
(3.6)\end{array}$ & $\begin{array}{l}\text { 1x before } \\
\text { each } \\
\text { vaginal } \\
\text { intercourse }\end{array}$ & 2142 & Low & Ghana \\
\hline $\begin{array}{l}\text { Richardson } \\
2000\end{array}$ & $\begin{array}{l}\text { Nonoxynol- } \\
9 \text { Gel }\end{array}$ & $\begin{array}{l}\text { Nonoxynol-9 } \\
\text { Placebo }\end{array}$ & $\begin{array}{l}\text { High Risk } \\
\text { Females }\end{array}$ & 28 & $\begin{array}{l}1 \mathrm{x} \text { before } \\
\text { first } \\
\text { vaginal } \\
\text { intercourse } \\
\text { of the day }\end{array}$ & 278 & Unclear & Kenya \\
\hline $\begin{array}{l}\text { Skoler- } \\
\text { Karpoff } \\
2008\end{array}$ & $\begin{array}{l}\text { Carraguard } \\
\text { Gel }\end{array}$ & $\begin{array}{l}\text { Methylcellulose } \\
\text { Placebo Gel }\end{array}$ & Females & 30.6 & $\begin{array}{l}1 \mathrm{hr} \text {. before } \\
\text { each } \\
\text { vaginal } \\
\text { intercourse }\end{array}$ & 6202 & Unclear & South Africa \\
\hline $\begin{array}{l}\text { Van } \\
\text { Damme } \\
1998\end{array}$ & $\begin{array}{l}\text { COL-1492 } \\
\text { (nonoxynol- } \\
\text { 9) Gel }\end{array}$ & $\begin{array}{l}\text { Nonoxynol-9 } \\
\text { Placebo Gel }\end{array}$ & Females & 31 & $1 x /$ day & 375 & Unclear & $\begin{array}{l}\text { Netherlands, } \\
\text { Belgium, } \\
\text { Thailand }\end{array}$ \\
\hline $\begin{array}{l}\text { Van } \\
\text { Damme } \\
2002\end{array}$ & $\begin{array}{l}\text { COL-1492 } \\
\text { (nonoxynol- } \\
\text { 9) Gel }\end{array}$ & $\begin{array}{l}\text { Repels } \\
\text { polycarbophil }\end{array}$ & $\begin{array}{l}\text { High Risk } \\
\text { Females }\end{array}$ & 26 & $\begin{array}{l}1 \mathrm{x} \text { before } \\
\text { each } \\
\text { vaginal } \\
\text { intercourse }\end{array}$ & 892 & Unclear & $\begin{array}{l}\text { Benin, } \\
\text { South } \\
\text { Africa, Côte- } \\
\text { d'Ivoire, } \\
\text { Thailand }\end{array}$ \\
\hline $\begin{array}{l}\text { Van } \\
\text { Damme } \\
2008\end{array}$ & $\begin{array}{l}\text { Cellulose } \\
\text { Sulphate } \\
\text { Gel }\end{array}$ & Placebo Gel & Females & 28 & $\begin{array}{l}\text { 1x before } \\
\text { each } \\
\text { vaginal } \\
\text { intercourse }\end{array}$ & 1425 & Unclear & $\begin{array}{l}\text { Benin, India, } \\
\text { South } \\
\text { Africa, } \\
\text { Uganda }\end{array}$ \\
\hline
\end{tabular}




\section{Figures}

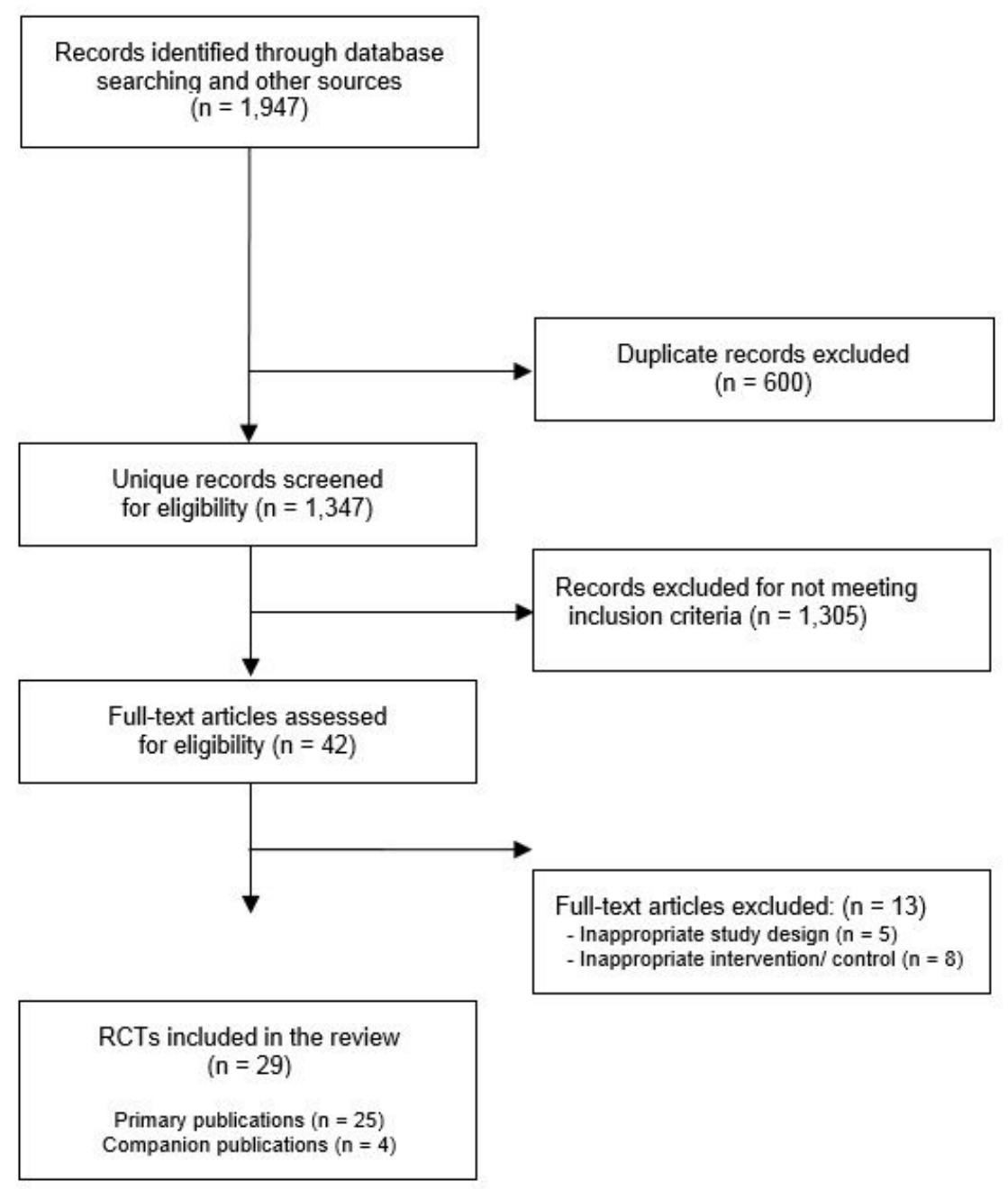

\section{Figure 1}

Modified PRISMA Flow Chart 


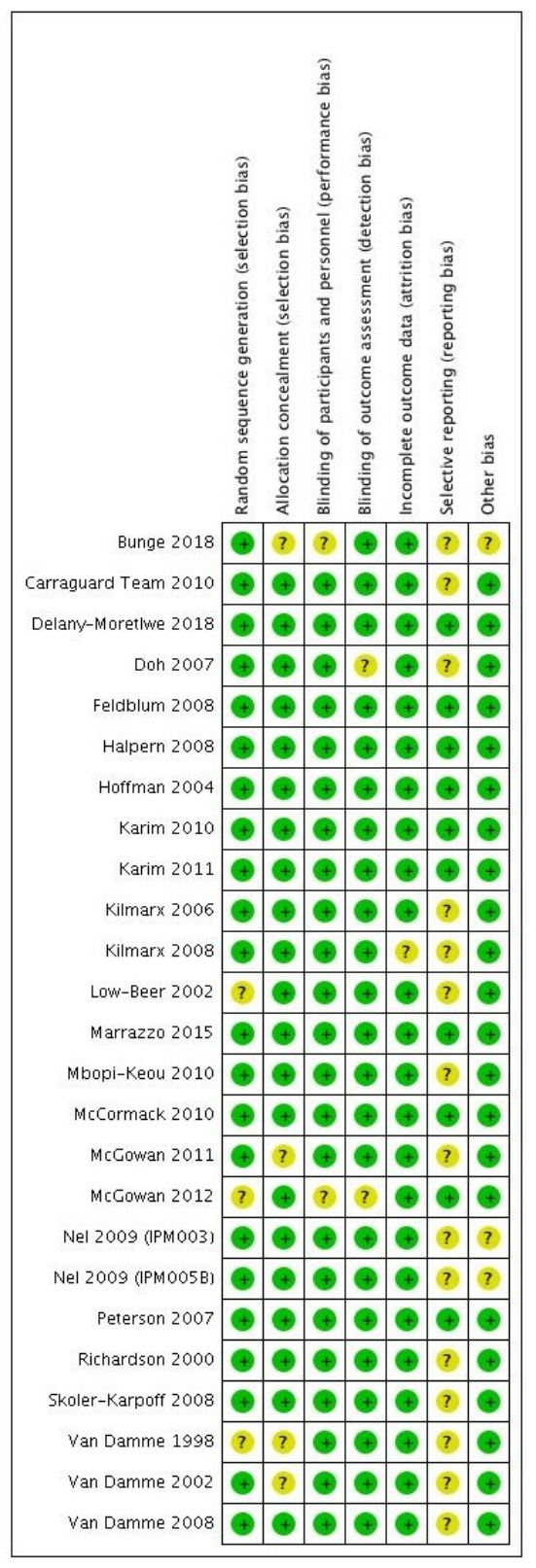

Figure 2

Risk of Bias Summary 


\subsection{1 .1 Nonoxynol-9}

Richardson 2000

Van Damme 2002

Subtotal $(95 \% \mathrm{CI})$

Total events

$\begin{array}{lllll}12 & 139 & 16 & 139 & 2.6 \%\end{array}$

$0.75[0.37,1.53]$

$1.29[0.90,1.86]$

Heterogeneity. $\mathrm{Tau}^{2}=0.07 ; \mathrm{Chi}^{2}=1.79, \mathrm{df}=1(\mathrm{P}=0.18) ; \mathrm{I}^{2}=44 \%$

Test for overall effect: $z=0.29(P=0.78)$

\subsubsection{SAVVY Ge}

Feldblum 2008

Peterson 2007

Subtotal $(95 \% \mathrm{CI})$

Total events

$\begin{array}{rrrrr}21 & 1076 & 12 & 1077 & 2.7 \% \\ 8 & 1073 & 9 & 1069 & 1.5 \%\end{array}$

$\begin{array}{llll}1073 & 9 & 1069 & 1.5 \% \\ 2149 & & 2146 & 4.2 \%\end{array}$

29

21

Heterogeneity $\mathrm{Tau}^{2}=0.05 \cdot \mathrm{Chi}^{2}=1.28, \mathrm{df}=1(\mathrm{P}=0.26) \cdot \mathrm{I}^{2}=22 \%$

Test for overall effect: $Z=0.89(P=0.37)$

\subsubsection{Carraguard}

Carraguard Team 2010

Skoler-Karpoff 2008

Subtotal $(95 \% \mathrm{CI})$

Total events

$\begin{array}{rrrrr}8 & 205 & 8 & 195 & 1.5 \% \\ 134 & 3103 & 151 & 3099 & 16.6 \% \\ & 3308 & & 3294 & 18.1 \%\end{array}$

$0.89[0.71,1.11]$

Heterogeneity. $\mathrm{Tau}^{2}=0.00 ; \mathrm{Chi}^{2}=0.02, \mathrm{df}=1(\mathrm{P}=0.89) ; \mathrm{I}^{2}=0 \%$

Test for overall effect: $Z=1.04(P=0.30)$

1.11.4 Tenofovir

Delany-Moretlue 2018

Karim 2010

Marrazzo 2015

Subtotal $(95 \% \mathrm{Cl})$

$\begin{array}{rrrrr}61 & 1015 & 62 & 1014 & 9.4 \% \\ 38 & 445 & 60 & 444 & 7.8 \%\end{array}$

Total events

$\begin{array}{llll}70 & 1003 \quad 9.9 \%\end{array}$

2467

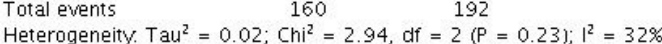

Test for overall effect: $Z=1.53(P=0.13)$

1.11.5 Buffer Gel

Karim 2011

Subtotal $(95 \% \mathrm{CI})$

Total events

$\begin{array}{lllll}54 & 775 & 51 & 771 & 8.4 \%\end{array}$

$.75[0.87,3.54]$

$.89[0.34,2.29]$

$1.35[0.70,2.58$

Heterogeneity

Test for overall effect: $Z=0.28(P=0.78)$

1.11.6 PRO 2000

Karim 2011

McCormack 2010

Subtotal $(95 \% \mathrm{CI})$

$\begin{array}{lllll}36 & 769 & 51 & 771 & 6.9 \%\end{array}$

$\begin{array}{lllll}31 & 6060 & 143 & 3325 & 18.7 \%\end{array}$

6829

Heterogeneity $\mathrm{Tau}^{2}=0.00 ; \mathrm{Chi}^{2}=0.91, \mathrm{df}=1(\mathrm{P}=0.34) ; \mathrm{I}^{2}=0 \%$

Test for overall effect: $z=1.76(\mathrm{P}=0.08)$

1.11.7 Cellulose Sulphate

Halpern 2008

Van Damme 2008

$\begin{array}{lllll}10 & 820 & 13 & 824 & 2.0 \%\end{array}$

Subtotal $(95 \% \mathrm{Cl})$

Total events

1537

$1532 \quad 5.5 \%$

Heterogeneity. $\mathrm{Tau}^{2}=0.10 ; \mathrm{Chi}^{2}=1.74, \mathrm{df}=1(\mathrm{P}=0.19) ; \mathrm{I}^{2}=43 \%$

Test for overall effect: $Z=0.42(P=0.68)$

Total $(95 \% \mathrm{CI})$

Total events

17653

Heterogeneity. $\mathrm{Tau}^{2}=0.01 ; \mathrm{Chi}^{2}=15.96, \mathrm{df}=13(\mathrm{P}=0.25) ; \mathrm{I}^{2}=19 \%$

Test for overall effect: $Z=1.27(\mathrm{P}=0.21)$

Test for subgroup differences: $\mathrm{Chi}^{2}=4.06, \mathrm{df}=6(\mathrm{P}=0.67), \mathrm{I}^{2}=0 \%$

$0.98[0.70,1.38]$

$.63[0.43,0.93]$

$0.87[0.62,1.21]$

$0.83[0.65,1.06]$

$1.05[0.73,1.52]$

$1.05[0.73,1.52]$

$0.71[0.47,1.07]$

$.89[0.72,1.09]$

$0.85[0.71,1.02$

$0.77[0.34,1.75]$

$1.54[0.83,2.86]$

$1.15[0.59,2.25]$

$0.93[0.82,1.04]$

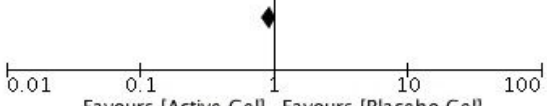

Favours [Active Gel] Favours [Placebo Gel]

Figure 3

Forest plot of HIV incidence 